\title{
The European Union after 9/11: The Demise of a Liberal Democratic Asylum Regime?
}

\author{
Dr. Carl Levy \\ Department of Politics \\ Goldsmiths College \\ University of London \\ New Cross \\ London SE14 6NW \\ UK \\ c.levy@gold.ac.uk
}

National Europe Centre Paper No. 109

Not for quotation without permission from the author

$$
\text { Copyright } \odot 2003 \text { (PSA) }
$$

Panel 9-8

EU Migration and Refugee Policy: After Tampere, Fortuyn and Le Pen- Where Next?

Political Studies Association $53^{\text {rd }}$ Annual Conference

University of Leicester, $15^{\text {th }}-17^{\text {th }}$ April 2003 
Introduction

In the past ten years the European Far Right has scored notable electoral victories in Scandinavia, Austria, Italy, the Low Countries, Switzerland, France, Portugal and elsewhere. There are many reasons why the Far Right has improved its electoral performance in domestic European elections. However, the one common denominator shared by this disparate group of political parties is a harsh stance against asylum seekers and refugees. On the face of it, the situation is paradoxical: There were two great surges of refugees and asylum seekers in the1990s. The first occurred during the war in Croatia and Bosnia (1992-1993) and the second took place during the upsurge of violence and ethnic cleansing in Kosovo (1998-1999). However, due to a series of bilateral, intergovernmental and EU policies, it has been increasingly difficult for forced migrants to seek refuge in Europe. 'The number of persons seeking asylum in the EU in 1992 was 675,460 and in 2001 this number had dropped to $384,530 .^{2}$ So while numbers have nearly halved in a decade, the issue is more controversial and visible than ever. There has always been a security dimension to the co-ordination of the movement of peoples across the borders of Europe. But has the liberal democratic tradition of asylum, embodied in the Geneva Convention of 1951, been sacrificed due to the dual pressures of the electoral victories of the Far Right in Europe and a new form of terrorism, which threatens European societies? Will European governments

\footnotetext{
${ }^{1}$ C. Levy, 'European Refugee and Asylum Policy after the Treaty of Amsterdam: The Birth of a New Regime?', in A. Bloch and C. Levy (eds.), Refugees, Citizenship and Social Policy in Europe, Macmillan, Basingstoke, 1999, p. 12-50; A. Geddes, Immigration and European Integration. Towards Fortress Europe?, Manchester University Press, Manchester, 2000; S.Lavenex, The Europeanisation of Refugee Policies. Between human rights and internal security, Ashgate, Aldershot, 2001.

${ }^{2}$ UNHCR. M. Bright, 'Asylum crisis hyped in Europe, says UN', The Observer, 2 June 2002, p.5.
} 
disavow the principle of non-refoulement and Article 3 of the Convention Against Torture in order to secure their homelands? In short will failed asylum applicants and terrorist suspects claiming asylum be sent back to unsafe countries where they might suffer torture? According to the Treaty of Amsterdam (1997) and the Tampere Declaration (1999), the European Union will start to formulate a common policy on refugees and asylum seekers after 2004. Will the European Union create an 'Area of Freedom, Security and Justice' as the Treaty of Amsterdam promises? Or will the fundamental rights of the Geneva Convention and the European Convention of Human Rights be violated and even sacrificed in order to protect Europeans from the greater threat of global terrorism?

The treatment of refugees using the UNHCR guidelines, the abolition of the death penalty and a more expansive welfare state have been placed forward as a West European model of liberal democracy, which in recent decades has been contrasted to its American ally across the Atlantic. Since September $11^{\text {th }}$, tensions over the possible extradition of terrorist suspects from Europe to the USA, who might face the death penalty, have underscored these differences. The UNHCR can still rely on the European Union to defend the sanctity of the Geneva Convention, both publicly and in documents, but there are manifest contradictions between the drive to securitise European Union immigration policy and demands to deepen elements of freedom and justice in the proposed 'Area of Freedom, Security and Justice'. Turning the immigration issue into a security issue plays into the hands of the Far Right, which the European Union has publicly denounced in the recent controversies over the political 
colour of an Austrian government. ${ }^{3}$ But failure to deal with fears may lead to greater insecurity and increased support for the Far Right in Europe.

This paper will illustrate in a most relevant and painful way the paradoxes of European liberal democracy. The argument is approached by firstly examining the extent to which the rise of the Far or Populist Right has pressurised the European Union into becoming more intolerant, and then it proceeds to examine to what extent the threat of terrorism has undermined the liberal democratic consensus (outlined above). The argument is therefore pitched at two levels: the effects of domestic politics on the national policies of Member States and the inputs of Member States on the joint policies of the European Union. Elsewhere I have used this argument as an illustrative case study in the wider debate about the nature of multi-level governance in the European Union and the associated debate about the extent to which the European Union had taken on the attributes of a sovereign nation-state. ${ }^{4}$ Here I can only declare my interest, but of course this interest does shape the way I will pitch my argument.

The events of September $11^{\text {th }}$ deepened the strains and fissures in the emergent postAmsterdam European refugee and asylum regime. And yet the entire system seemed

\footnotetext{
${ }^{3}$ A. Wahlrab, 'The Case of Austria: Policing Democratic Values in the Global North', Workshop 4, $30^{\text {th }}$ Joint Sessions Workshops, European Consortium for Political Research (ECPR), Edinburgh, UK, 28 March-2 April 2003.

${ }^{4}$ C. Levy, 'Harmonisation or Power Politics? EU Asylum and Refugee Policy Five Years After Amsterdam', ECPR Workshop 23, 'Immigration Politics: Between Centre and Periphery', ECPR Joint Sessions of Workshops, Turin, 22-27 March 2002. For a good account of debates over multi-level governance in the European Union see, M. A. Pollack, The Engines of European Integration. Delegation, Agency, and Agenda Setting in the EU. Oxford University Press, Oxford, 2003. For excellent studies that apply this approach to the European Union's and the Member-States' policies on asylum seekers, refugees and immigration see, V. Guiraudon, 'The constitution of a European immigration domain: a political sociology approach', Journal of European Public Policy, vol. 10, no.2, 2003, pp. 263-82; A. Geddes' 'Still Beyond Fortress Europe: Patterns and Pathways in EU Migration Policy', PSA Annual Conference, University of Leicester, 14 -16 April 2003.
} 
to be unravelling before 2001: witness the distress of the Dublin Convention. ${ }^{5}$ The European Commission, mindful of the increasing demands to restrict the flows of refugees and asylum seekers into Europe carefully and then rather boldly suggested that Europe had to review the post-1973 stop on labour migration into Europe. During the late 1990s boom this was being revised by various Member States at the national level. The European Commission argued that migrants were needed for the European economy and for the future viability of the continent's pensions system. These needs were recognised and the recruitment of workers from the rest of the world was officially sanctioned for the first time since the official stop in the wake of the 1973 oil-shock. The link between forced migration caused by economic hardship or by war and persecution was made. Such a policy might undermine the Geneva Convention, a topic I have discussed elsewhere, since the Convention should not be interpreted as ad-hoc form of immigration policy but an international obligation of the signatories to consider the claims of applicants fleeing persecution. The argument had been muddied because by the 1990s more than $90 \%$ of all asylum seekers in Europe were not granted full Convention status, but allowed to stay in Member States under ad hoc conditions because they were either displaced from the wars of the Yugoslav succession, or considered endangered by Home Offices or national courts if they were forcibly repatriated, even if they could not meet the stricter standards of proof demanded by the Convention to secure full refugee status. ${ }^{6}$

\footnotetext{
${ }^{5}$ N. Blake, 'The Dublin Convention and the Rights of Asylum Seekers in the European Union', in E. Guild and C. Harlow (eds.), Implementing Amsterdam: Immigration Rights in EC Law, Hart Publishing, Oxford, 2001, pp. 90-120.

${ }^{6}$ C. Levy, 'The Geneva Convention and the European Union: A Fraught Relationship'. in J. van Selm, K. Kamanga, J. Morrison, A Nadig, S. Spoljar Vrzina and L. van Willigen (eds.), The Refugee Convention at 50: a view from Forced Migration Studies, Lexington Books, Lanham, MD, 2003 pp. 129-44 .
} 
The linkage made between the erosion of the Geneva Convention and the demands for labour in the documents of the Commission might also cause Europe to realise that it is and has always been a continent of immigration and migration. It was implied that many forced migrants arriving in Europe inhabited a grey area between Convention refugees and economic migrants. This of course was part of a much longer trend in European migration policy. During the Cold War, when most refugees came from the Soviet bloc, the Convention was largely unproblematic. And during the Great Boom before 1973, the demand for labour made a grey area unnecessary. A migrant could easily find employment in Europe and a refugee would be welcomed as a victory for the West over the East.

The cautious and then bold return to labour recruitment by the European Union thus fits into an historical pattern stretching back decades. In 2000, the European Commission signalled a new, more liberal policy on immigration in a communication to the Council of Ministers and the European Parliament. ${ }^{7}$ The Commission called on the Council and Parliament to rethink Europe's zero immigration policy, stating that 'channels for legal immigration to the Union should now be made available to labour migrants. ${ }^{8}$ The Commission noted 'growing shortages of labour at both the skilled and unskilled levels.' ${ }^{9}$ The Commission concluded: 'while immigration will never be a solution in itself to the problems of the labour market, migrants can make a positive contribution to the labour market, to economic growth and to the sustainability of

\footnotetext{
${ }^{7}$ COM (2000) 757 final, 'Communication from the Commission to the Council and the European Parliament on a Community Immigration Policy’, Brussels, 22 November 2000

${ }^{8}$ Ibid, p. 2.

${ }^{9}$ Ibid, p. 3.
} 
social protection systems. ${ }^{10}$ This might have signalled a paradigm shift in European Union immigration policy.

Furthermore, earlier, the Nice inter-governmental conference in December 2000 seemed to underline the importance of treating long-term third country nationals more fairly. Thus the boundaries between refugees, forced migrants granted special leave to remain and economic migrants was somewhat eroded. The Commission's proposed Council Directive on the status of third country nationals who were longterm residents (March 2001) set out measures to ensure comparable treatment with Union citizens in terms of normative and practical grounds. Thus the needs of 'the employment market, the effective attainment of the internal market, and the enhancement of economic and social cohesion (Articles 2 and 3(1)(k) of the TEC)' (are ensured through) 'the integration of third country nationals."1 However this trend towards liberalisation seemed to be stopped dead in its tracks by the events of September $11^{\text {th }}$ 2001. Differences were emphasised and the need to address security issues were underlined. The extraordinary Justice and Home Affairs Council meeting of 20 September 2001 asked ' the Commission to examine urgently the relationship between safeguarding internal security and the complying with international protection obligations and instruments'.12 On 5 December 2001 the European Commission issued a Working Paper which encouraged Member States to 'scrupulously and rigorously' apply the exclusion clauses contained in Article 1(F) of

\footnotetext{
${ }^{10}$ Ibid. p. 21.

${ }^{11}$ T. Kostakopoulou, “ “ Integrating” Non-EU Migrants in the European Union: Amibivalent Legacies and Mutating Paradigms', The Columbia Journal of European Law, Vol. 8, No. 2, Spring 2002, p194, p. 195, pp. 197-8. Also see, T. Kostakopoulou, 'The 'Protective Union': Change and Continuity in Migration Law and Policy in Post-Amsterdam Europe', Journal of Common Market Studies, Vol. 38, No.3, 2000, pp. 497-518.

${ }^{12}$ SN 3926/6/01, Conclusions adopted by the Justice and Home Affairs Council, Brussels, 20 September 2001, Conclusion 29.
} 
the Geneva Convention in order to prevent persons suspected of terrorist acts from seeking asylum. The Commission suggested that:

pre-entry screening, including strict visa policy and the possible use of biometric data, as well as measures to enhance co-operation between border guards, intelligence services, immigration and asylum authorities of the State concerned, could offer real possibilities for identifying those suspected of terrorist involvement at an early stage. ${ }^{13}$

Furthermore a common position adopted by the EU on 27 December 2001, required that Member States investigate refugees and asylum seekers 'for the purpose of ensuring that the asylum seeker has not planned, facilitated or participated in the commission of terrorist acts. ${ }^{14}$ Thus the competing policy tradition of the securitisation of migration and refugee policy in Europe once again became the agenda-setter after September $11^{\text {th }} .^{15}$

This discussion demonstrates the difficulties of evaluating the contrary influences of politics, the economy and law, and the role of liberal democratic values in the formulation of policy. Sociological or IR realist approaches would quickly dismiss the issue of liberal democratic values as naïve: clearly the Convention was used as a tool of the Cold War and was at the mercy of long-term trends in European demographics and the labour market since the 1950s. But this does miss the point. Formal

\footnotetext{
${ }^{13}$ COM (2001) 743 final, 'The relationship between safeguarding internal security and complying with international protection obligations and instruments', Commission Working Document, Brussels, 5 December 2001, p.6.

${ }^{14}$ 2001/931/CFSP, Council Common Position of 27 December 2001 on Combating Terrorism, Article 16.

${ }^{15}$ For an analysis of this policy tradition see, J. Huysman, 'The European Union and the Securitization of Migration, Journal of Common Market Studies, Vol. 38, No.5, pp. 751-77. For policy since September $11^{\text {th }}$ see, T. Faist, 'Extension du domaine de la lutte: International Migration and Security before and after 11 September 2001', International Migration Review, Vol. 36, No. 1, 2002, pp. 7-8; G. Karyotis, 'European Immigration Policy in the aftermath of September 11: Reinvigorating the
} 
acceptance of the Convention is the guarantor of a liberal democratic benchmark.

The sovereign signatories have promised to defend the principle of non-refoulement.

National courts have refused to deport failed asylum applicants to what they

considered unsafe third countries or to their homelands if they felt their lives were

under threat or they faced possible torture. Without the Geneva Convention and the

Torture Convention, the national courts would have no recourse to an internationally

sanctioned set of liberal democratic ground-rules. The sovereign signatories are

obliged to consider the cases of applicants, and it is for them as nation-states to

determine who is and who isn't a Convention Refugee. But without the Geneva

Convention, the determination of refugee status would be entirely seen as a gift of

each nation-state rather than an obligation backed by international law. A 'realist'

approach to this subject fails to explain the actual policy outcome. Even if the

Convention has failed in nine out of every ten cases, asylum seekers were given some

sort of landed status in Europe during the 1990s. It served as the moral and legal

benchmark for the entire system. Without it, those under temporary protection

regimes would be under far greater threat of deportation. ${ }^{16}$

Securitisation Discourse', UACES Annual Conference, Queen's University Belfast, 2-4 September 2002; J. van Selm, 'Refugee Protection in Europe and the US after 9/11', forthcoming.

${ }^{16}$ The boundaries between forced migration and economic migration their effects on politics of liberal democracy is interestingly discussed in a new overview see, B. Jordan and F. Düvell, Migration. The Boundaries of Equality and Justice, Polity, Cambridge, 2003:

Migration illustrates the precarious balance between the power of global and regional regimes and that of nation states. Freedom of movement for the purposes of business, study and tourism has become established throughout the world under rules sustained through international agreements. There is an international convention on rights to humanitarian protection for victims of war and oppression. But rules who can work, who can settle and who can become a citizen are still the province of national governments. The tension between these three systems, existing side by side, is reflected in periodic 'moral panics' about immigration, asylum seeking, race relations and the cultural basis for political communities in First World countries' (p.17). 
To what extent did the increasing prominence of the Far or Populist Right in Europe undermine this benchmark at the Member-State level of governance? The next section of this paper addresses this question.

2. The Far Right and Mainstream Political Parties: Reshaping Asylum Seeker Policy at the Domestic Level?

In reaction to September $11^{\text {th }}$ the Far and/or Populist Right was reinvigorated, though one must note that the effect was not uniform throughout Europe. Certainly the surprisingly strong showing for the hard-line maverick magistrate, Ronald Schill, in Hamburg's elections in September 2001 can be tied to the fact that the leader of the hijackers of the planes that crashed in the Twin Towers lived in that city for many years. ${ }^{17}$ The flash victory of the Dutch Populist, the assassinated Pim Fortuyn, can be tied to his Islamophobia. Indeed the ground was well prepared: after a poll of Muslims indicated that a small percentage applauded the attacks on the Twin Towers, another poll of Dutch citizens demonstrated that 63 per cent felt that radical Muslims should be removed from the country. And generally two thirds of Dutch citizens feared that the integration of Muslims into Dutch society would be hindered by reactions to the attacks. Fortuyn exploited a 'gap' in the political market, he did not

\footnotetext{
${ }^{17}$ H. Simonian and H. Williamson, 'SPD seeks partners after Hamburg upset', Financial Times, 25 September 2001, p. 12.
} 
create it. ${ }^{18}$ Although Jean Marie Le Pen has been around for decades and his ability to enter the second round of the French Presidential elections in June 2002 owed a great deal to the disarray of the French Left, his Islamophobic and anti-migrant discourse did find new support after September $11^{\text {th }} .^{19}$ The narrowly defeated referendum championed by the populist businessman leader of the SVP, Christoph Blocher, which would have essentially forced Switzerland out of the Geneva Convention of 1951, seemed to also be partially influenced by the events of the last year, though other issues were invoked by the campaigners. ${ }^{20}$

Nevertheless the influence of the Far Right on the governing and/or mainstream parties is neither clear-cut nor self-evident. First, what parties are we talking about? ${ }^{21}$ Some of the most notable gains for the Far and Populist Rights have been in consociational or consensual democracies (Norway, Denmark, Belgium, the Netherlands, Austria and Switzerland), where charismatic populist politicians like Jörg Haider in Austria, the deceased Pim Fortuyn in the Netherlands or Carl Hagen in Norway posed as outsiders, undermining the cosy cartels that have run national politics for decades and claiming to tell the 'truth' about the 'scandal' of unhindered migration and rampant multi-culturalism. But the Far Right has also appealed to

\footnotetext{
${ }^{18}$ C. Mudde 'The Pink Populist: Pim Fortuyn for Beginners', E-Extreme, Electronic Newsletter of the ECPR-SG on Extremism \& Democracy, Vol. 3, No.2, 2002, pp. 3-6; van Selm, forthcoming; J. J. M. Van Holsteyn, G. A. Irwin and J. M. Den Ridder, 'In the eye of the beholder. The preception of the List Pim Fortuyn and the parliamentary elections of May 2002', Acta Politica, 38, 1, 2003.

${ }^{19}$ D. S. Bell, 'The Election of Extremes', E-Extreme, Electronic Newsletter of the ECPR-SG on Extremism \& Democracy, Vol. 3, No. 2, 2002, pp. 1-3.

${ }^{20}$ J. Henley, 'Swiss reject harsh asylum laws-just', The Guardian, 25 November 2002, p. 15.

${ }^{21}$ For the must recent overview of the Far or Populist Right see, K. Arzheimer et. al, 'Comparative Mapping of the Extreme Right Electoral Dymamics: an overview of EREPS (Extreme Right Electorates and Party Success)', European Political Science, Vol 1, No. 1, 2001, pp. 42-5,C. Mudde, The Ideology of the Extreme Right, Manchester University Press, Manchester, 2002, C. Mudde, 'Extremist Movements', in P. Heywood, E. Jones and M. Rhodes (eds), Developments in West European Politics 2, Palgrave, Basingstoke, 2002, pp. pp. 135-50, C. Levy, “ "There is something nasty in the woodshed". The Far Right and Conservatives in Consensual and Consociational Democracies: A
} 
regionalisms (Filip Dewinter in Belgium and Umberto Bossi in Italy). The Alleanza Nazionale in Italy drew its support from elements of southern Christian Democracy after the collapse of the Second Republic ten years ago. Similarly new 'political space' helped Jean Marie Le Pen's success in getting into the final round of the Presidential elections: in this case the failure of the Left at mounting a coherent unified campaign against the Centre-Right in the first round.

But victory has rapidly turned to defeat if party structures were weak or non-existent, the most spectacular case here is the collapse of the Pim Fortuyn List following the death of its leader. Or victory was thrown away if the charismatic leader behaved in an erratic, extreme or egotistical manner, as was the case to a certain extent for Bossi and the Lega Nord and Haider and the Freedom Party. Alternatively, the Danish People's Party, the Norwegian Progress Party, Belgium's Vlaams Blok, the Italian Alleanza Nazionale and the French Front National have well organised party machinery that have embedded them in the political system.

Whether or not it makes sense to place all these parties in the same family is another question, which is beyond the scope of this paper. Some of these parties find their origins in breakaways from mainstream Christian Democrat and Liberal parties. Some of them have evolved from historical fascist antecedents. Others might be closer to neo-liberal charismatic politics. Yet none can be directly equated with historical fascism - they all praise democracy, few of them dream of imperial conquest (although Vlaams Blok dreams of a greater Flemish homeland) and anti-communism has an antiquated air to it (even if it still is used in Italy). Neither have they 
recognised a mutual kinship. Before his death Fortuyn denounced Haider and Le Pen. Indeed he characterised his politics as like Berlusconi's but with less money. The life style of the openly gay Fortuyn must have scandalised Le Pen or the Scandinavian Populists. Some of these parties embraced neo-liberalism at home and abroad: others were rather more critical of it. Some of these parties endorsed the EU, but most were critics. What they all shared however was a core ideology that vigorously criticised multi-cultural society. They all demanded strict assimilation for migrants to a homogenised national culture. They advocated a 'welfare state chauvinism', namely, a welfare state for the assimilated and lesser forms of assistance for other residents of their country. And these core values were melded together by a policy of strict restriction of migration and the right of asylum in their country. ${ }^{22}$ Thus the charismatic leader embodied the 'common sense' of the average, forgotten citizen, who had been an alien in his own land. The use of direct tele-visual democracy, earthy language and referenda were seen as a way to circumvent the special interests that had prevented the message of the 'real' people from being heard. But if the restriction of migration and the right of asylum was the common factor shared by all of these parties, the measured effects on policy in any given country varied.

A direct influence can be detected in countries where a Far or Populist Right party has joined a coalition or whose votes were needed by a coalition in order to stay in power. ${ }^{23}$ The most spectacular case was the Danish People's Party, where although it remained outside of power, the Centre-Right coalition enacted legislation that

\footnotetext{
to $2002^{\prime}$, forthcoming.

${ }^{22}$ For analysis of the new populism see, Y. Mény and Y. Surel, Par le peuple, pour le peuple, Librairie Arthème Fayard, 2000.

${ }^{23}$ A recent good survey can be found in John Lloyd's, 'Europe's New Politics. No to Brussels, No to immigration: how rightwing populism entered the mainstream', Financial Times. 28 November 2002, p. 21.
} 
severely restricted entry into Denmark by refugees and asylum seekers, enforcing strict citizenship and residency requirements, which may violate international human rights law. On the other hand although two Far or Populist Right parties in Italy are part of Berlusconi's coalition government and have been influential in the formation of asylum and refugee law, real effects have been diluted through the influence of the tradition of Catholic solidarity, employers' voices and the impenetrability of 'economic informality'..$^{4}$

But the influence of the Far and Populist Right can also be measured by anticipatory or reactive responses by mainstream politicians of the Centre-Right and Centre-Left. In the Netherlands, in March 2002, on the eve of the municipal elections and two months before the flash victory of Fortuyn in the polls, the Secretary of State for Justice, Ella Kalsbeck, suggested in an interview that Afghan refugees might be forcibly repatriated in the longer-term. ${ }^{25}$ The Home Secretary of the British Labour government, David Blunkett, piloted the Nationality, Immigration and Asylum Act through Parliament, which closed illegal routes for asylum seekers and refugees, and advocated settlement camps, while expediting citizenship applications for those who would boost the UK economy. Nicolas Sarkozy, the Interior Minister of France in the new Centre-Right government, guided the Law on Internal Security though the National Assembly, that was designed to reassure the electorate that spiralling crime rates are being tackled and illegal immigration was being kept down. Otto Schily, the German Interior Minister, in the recently re-elected Social Democrat-Green coalition

\footnotetext{
${ }^{24}$ L. Morris, Managing Migration. Civic Stratification and Migrants' Rights, Cambridge University Press, Cambridge, 2002, pp. 53-79; G. Zincone, 'Immigration Policy-Making in Italy: An Eclectic Interpretative Approach', European Consortium for Political Research, Worskhop 23, Immigration Policies: Between Centre and Periphery, National States and the EU, Turin, 22-27 March 2002; A. Geddes, The Politics of Migration and Immigration in Europe, Sage, London, 2003, pp. 157-60. ${ }^{25}$ van Selm, forthcoming.
} 
did take measures against the Extreme Right and guided legislation that granted (mainly Turkish) guest workers the right to German citizenship. But he also introduced tougher measures to combat crime and saw the Immigration Act passed by the Bundestag, which would control and limit the number of immigrants allowed to take up legal residence. ${ }^{26}$ Thus the restrictive agenda in the hands of Centre-Left governments that came to power in the late 1990s seems to have been pursued by reelected governments or in their replacements. ${ }^{27}$ However, on the other hand a certain opening to immigration and citizenship for long-term residents is also present that the Far or Populist Right finds anathema. Governments have argued that they want to be more restrictive in order that genuine asylum seekers are granted refugee status and those who are allowed to stay are more easily integrated into their host society.

The next section of this paper examines how the domestic agendas of the Member States have affected the policies of the European Union. It will show that there is no clear transferral of policy trends from the domestic level to the European level. This means that so far the European Union moderates the more restrictive policies of the Member States. On the other hand the European Union's common policy is still lacking any real teeth. And despite the political voices of the Commission, the European Parliament and even the European Council defending the ethics behind the Geneva Convention, inter-governmental co-operation of interior and security officials assisted in the securitisation of European Union policy long before September $11^{\text {th }}$.

\footnotetext{
${ }^{26}$ J. Lloyd. 'Europe's New Politics', Financial Times, 29 November 2002, p. 17.

${ }^{27}$ L Schuster, 'A comparative analysis of asylum policy of seven European governments, Journal of Refugee Studies, vol. 13, no. 1, 2000, pp. 1-15.
} 


\section{The European Union and the Member States: Restrictionism and the legacy of} the Geneva Convention

I have argued that restrictionism seems to have taken the initiative in European policy-making since September $11^{\text {th }}$. Nevertheless the long-term attachment to the Geneva Convention has meant that the European Union has been hesitant to completely disavow its past. The USA kept the UNHCR at arm's length during most of the Cold War, openly using its asylum and refugee policy as a tool in its struggle against the Eastern Bloc. By contrast, in the 1960s and 1970s, Western Europe used the handbook of the UNHCR to develop best practice for the treatment of asylum seekers. ${ }^{28}$ In a survey of parliamentary debates about the reform of asylum and refugee law in Switzerland, Germany and the UK from the middle 1970s to the middle 1990s, a recent study has demonstrated that not a single parliamentarian demanded the renunciation of the Geneva Convention by their country's government. Even advocates of restriction saw the Geneva Convention as a 'constitutive part' of liberal society. ${ }^{29}$

The sanctity of international law and the Geneva Convention has been repeatedly defended in the official documents of the European Union and this sentiment can also be found in the informal minutes of the Heads of Government and State, as was the case just before the Tampere Conference when the German Federal Minister of the Interior, Otto Schily, and his French partner, Jean-Pierre Chévènement, addressed the future of European Union policy on asylum and immigration. While the Austrian

\footnotetext{
${ }^{28}$ G. Loescher, The UNHCR and World Politics. A Perilous Path, Oxford University Press, Oxford, 2001, pp. 176, 183, 185.
} 
Presidency paper of the previous year was a ghost at the banquet, questioning the future of the Geneva Convention, the Franco-German document reiterated the values of the Geneva Convention. 'Asylum is not immigration', the document argued, 'and in spite of the confusion kept up by false applicants, the control of migratory movements ought not undermine the Union's capacity of offering reception to those persecuted. ${ }^{30}$ The ministers stated that the opponents of the Geneva Convention should not use one form of cagey realism to undermine the bedrock principle of nonrefoulement. The ring-fenced solemn international obligation recognised as part of the case law of the Member States should not be elided into a discussion of general issues of migration. Thus even if more than 90 per cent of refugees in Europe did not get Convention status, it was still nearly impossible to deport them to countries where their lives might be endangered. A Member State in Europe might aspire to a zero immigration policy but it would be bound to accept asylum seekers on its territory so long as it remained a signatory of the 1951 Geneva Convention. And the Treaty of Amsterdam and the declarations at Tampere and Laeken by the European Council have consistently reiterated this position. Harmonisation of asylum and refugee policy and transparent burden-sharing of refugee inflows would save, not scupper, the Geneva Convention.

Radical solutions suggested by British Home Secretaries have been shot down. At the European Conference on Asylum, sponsored by the then current Portuguese Presidency of the EU (Spring 2000), Jack Straw called for a redrafting of the Geneva

\footnotetext{
${ }^{29}$ N. Steiner, Arguing about Asylum. The Complexity of Refugee Debates in Europe, Palgrave, Basingstoke, 2001. p. 149.

${ }^{30}$ Migration News Sheet, October 1999, p. 1. For a discussion of Tampere see, I. Boccardi, Europe and Refugees: Towards an EU Asylum Policy, Kluwer Law International, The Hague, 2002, pp. 175-80.
} 
Convention. ${ }^{31}$ He suggested an international quota system under which European countries would share asylum seekers from countries recognised as violators of human rights. Straw seemed to confuse temporary protection with the Geneva Convention system of individual determination of cases. The system would also undermine the concept of non-refoulement by creating an ad-hoc system of safe countries. However these suggestions were not immediately unsuccessful. After September $11^{\text {th }}$, the Home Secretary, David Blunkett, proposed a hard line at the Seville summit in the early summer of 2002. It may have been embraced by his fellow interior ministers, but it was felt too illiberal for the Heads of Government and State, who thought that tying the continuation of aid to developing countries to their co-operation at curbing illegal immigration was a violation of the spirit of the Geneva Convention and the international rights regime that formed part the European model. In the end we can see that a European model of international law and governance has been defended before and after September $11^{\text {th }}$.

Encounters with challenges to the consensus also demonstrate the degree to which the full-fledged demands of the Far and Populist Right have lacked support at the highest level of EU policy-making. The Austrian Presidency's and the British Home Secretaries' interventions mirror in a more polite and measured way key planks of these parties' more rough and tumble pronouncements. A more extreme example

\footnotetext{
${ }^{31}$ J. Straw, 'Towards a Common Asylum Procedure', European Conference on Asylum, Lisbon, 16 June 2000. More recently it has been reported that the British suggest the Australian route. All new asylum seekers would be immediately deported to Albania and possibly Croatia where their cases would be processed in specially built detention centres, 'Blunkett plans to send asylum seekers to Albania', Sunday Telegraph, 9 March 2003. This is also the subject of a forthcoming report by Demos/openDemocracy.net see, People Flow: Managing Migration in a a New European Commonwealth, written by Tom Bentley, Alessandra Buonfino and Theo Veenkamp, head of strategy at the Dutch Ministry of Justice and forner head of the Netherlands agency for the Reception of Asylum Seekers. It should be noted in passing that Dutch asylum policy was been severely criticised for violating international refugee standards by Human Rights Watch, see Fleeting Refuge: The Triumph of Efficiency over Protection in Dutch Asylum Policy, London, 2003.
} 
might be the conversion of the right of asylum from international law to charitable gift, or the tying of aid to the developing world to its co-operation in policing all forms of migration (which exists in the manifesto of the Danish People's Party). ${ }^{32}$ However this would preclude extreme parties from agreeing with the British call for some form of measured labour migration, as they might find their endorsement of the Treaty of Amsterdam's struggle against racism and xenophobia tiresome and 'politically correct'. Article 13 of the Treaty of Amsterdam was soon turned into two directives addressing racism and discrimination, partially, it has been argued, in response to the victory of the Freedom Party in Austria. ${ }^{33}$ Therefore this exercise does demonstrate that at least at the level of polite official conversation and even law, the European Union still could not stomach a fundamental challenge to its conception of the European role in the international regime of rights and law.

Nevertheless, the effects of September $11^{\text {th }}$ challenged the bedrock of the Geneva Convention, but this originated from the logic of security rather than the welfare chauvinism of the Far or Populist Right. Non-refoulement has been placed under severe pressure because of the threat of global terrorism - even if the Member States are opening their gates to greater economic migration, arguing that the boat is indeed not full, they are simultaneously promoting anti-racist strategies aimed at combating the Extreme Right. In debates held during the period 2001-3 the European Commission suggested that the suspension of a guarantee of non-refoulement in Article 3 of the European Convention on Human Rights might have to be ruled on by

\footnotetext{
${ }^{32}$ The Danish government (under the influence of the Danish People's Party) has suggested that the forthcoming Commission Directive on the definition of refugee/subsidiary protection include a clause in which all new successful applicants for refugee or subsidiary protection have their cases reviewed regularly in order to have their status terminated as soon as possible. This would be a grave blow to the Geneva Convention. But it remains to be seen if this will pass (The Guardian, 11 December 2002).

${ }^{33}$ Geddes, pp. 143-4.
} 
the European Court of Human Rights. The whole discussion of human rights, terrorism and the suspension of non-refoulement will be a complex and fraught subject. But it has had knock-on effects in the meantime. For example, the British Home Secretary, David Blunkett, announced (16 October 2001) that the UK would derogate from article 5 of the European Convention on Human Rights (only incorporated in UK law four years earlier), in order to allow the detention of a suspected terrorist in the UK where there is no extradition treaty with the country of origin or transit, or because he or she might face torture or death in that country. ${ }^{34}$

But the securitisation agenda preceded the new era of refugees and asylum-seekers. It was located in a tradition that grew up in the 1970 s concerned with international left-wing and right-wing terrorism from European citizens, Palestinians and secular Middle Eastern activists. It was found in the secretive enclaves of middle-level officials that have gone on for decades - trans-national and trans-governmental networks of working groups of police officials and civil servants from Ministries of the Interior or Home offices developed from the 'wining and dining' circles of the $1970 \mathrm{~s}^{35}$ In order to avoid the annoying opposition of national courts, other more liberal ministries and NGOs law and order officials employed the mechanism of supranational venues to avoid prying eyes. ${ }^{36}$ As has been recently argued, 'Trevi provided a 'security' frame into which migration issues were inserted when they rose up the political

\footnotetext{
${ }^{34}$ van Selm; E. Guild, 'Asylum, Borders and Terrorism: the Unexpected Victims of 11 September 2001'. forthcoming, pp. 14-15.

${ }^{35}$ V. Guiraudon, 'European Integration and Migration Policy: Vertical Policy-making as Venue Shopping', Journal of Common Market Studies, Vol. 38, No. 2, 2000, pp. 251-71, D. Bigo, 'Migration and Security', V. Guiraudon and C. Joppke (ed.), Controlling a New Migration World, Routledge, 2001, p. 121-49; D. Bigo, 'Migration and Security', in V. Guirandon and C. Joppke (eds.), Controlling a New Migration World, Routledge, 2001, pp. 99-120.

${ }^{36}$ V. Guiraudon and G. Lahav, 'A Reappraisal of the State Sovereignty Debate. The Case of Migration Control', Comparative Political Studies, Vol. 33, No.2, 2000, pp. 163-95.
} 
agenda from the late $1980 s^{\prime} .^{37}$ Thus an 'escape to Europe' allowed politicians to sanction illiberal policies outside of the framework of their own liberal democratic polity. ${ }^{38}$ These policy networks stressed security issues and drove the restrictive practices of 'Schengenland' and the Dublin Convention. Migration control was also shifted from national courts and other ministries to Home Offices or private entities. Airline officials became de facto immigration officials and buffer policies made it virtually impossible for spontaneous asylum seekers to reach most of the European Union without violating the law. Refugee policy in Europe had been regionalised. The disastrous policy of so-called safe areas during the Bosnian War or the more effective and noble burden-sharing and joint military action against a refugee-producing State in the Kosovo intervention emphasised the role of security and military networks. Burden-sharing agreements validated the temporary protection of Kosovar Albanians within Member-States' national territory but spontaneous refugees from Kosovo and elsewhere had to break the law in order to reach the Member States of the European Union to claim asylum. ${ }^{39}$

With legal routes of entry into the European Union blocked off, the position of spontaneous asylum seekers was further criminalised as the role of smuggling networks grew. ${ }^{40}$ The Far and Populist Right fed off the public disquiet this criminalisation produced and thus the well-established and secretive meso-level networks of law and order officials found a new justification for their long-standing policies. The transfer of policy-making from the security-conscious third pillar of the

\footnotetext{
${ }^{37}$ Geddes, p. 130.

${ }^{38}$ J. Hollifield, 'Ideas, Institutions and Civil Society: On the Limits of Immigration Control in France', in M. Brommes and A. Geddes (eds.), Immigration and Welfare: Challenging the Borders of the Welfare State, London, 2000.

${ }^{39}$ J. van Selm-Thorburn (ed.), Kosovo's Refugees in the European Union, London, 2000.
} 
European Union to the legal order of the European Court of Justice located in the first Community pillar of the Union did not easily counterbalance this influence. This nascent legal order will have to overcome a formidable barrier of personal contacts and unspoken assumptions or secretly discussed agreements long in place. In any case the Court of Justice has little say over asylum and refugee policy at this stage: the European Charter of Fundamental Rights may form a firmer basis for a judicial framework to protect asylum-seekers and refugees in the future, but at present it is not legally binding. ${ }^{41}$ We must wait to see if the European Constitutional Convention incorporates it into the new governing document of the European Union. The European Court of Justice still has little control over the technocrats and police officials, but neither in fact do the politicians. A joint policy on refugees and asylum seekers will necessarily be slow in coming since at Nice, the European Council decided against the introduction of qualified majority voting, thus demonstrating 'the enduring reluctance of the Member States to transfer sovereignty'. ${ }^{42}$ In the future there may be a clash between 'technocratic Europe' and a 'rights-based Europe': but at the present meso-level policy networks of security officials are still dominant and indeed since September $11^{\text {th }}$ far more so.

\section{Conclusion}

\footnotetext{
${ }^{40}$ J. Morrison and B. Crosland, The Trafficking and Smuggling of Refugees: The End Game in European Asylum?, UNHCR, Geneva,2000.

${ }^{41}$ G. S. Goodwin-Gill, 'The Individual Refugee, the 1951 Convention and the Treaty of Amsterdam', in E. Guild and C. Harlow (eds.), Implementing Amsterdam: Immigration Rights in EC Law, Hart Publisning, Oxford, 2001, pp. 141-63; S. Peers, 'Immigration, Asylum and the European Union Charter of Fundamental Rights', European Journal of Migration Law, Vol.3, 2001, pp. 141-69.

${ }^{42}$ S Lavenex, ' The Europeanization of Refugee Policies: Normative Challenges and Institutional Legacies', Journal of Common Market Studies, vol. 39, no. 5, 2001, p. 865.
} 
This paper has examined the effects on national and European asylum and refugee policy of the triangular relationship between the Far and Radical Populist Right in Member States, the Member States governments and the European Union. The guiding principles of European refugee and asylum policy have been set by the 1951 Geneva Convention and by the sanctity of non-refoulement. Recent commentators fear that this may well be sacrificed in the struggle against global terrorism. ${ }^{43}$ But even if it is not, other paradoxes arise. For example, the British government has derogated from the European Convention of Human Rights in order to instigate preventive detention of suspect terrorist refugees and asylum seekers because it wanted to adhere to its commitment to the principle of non-refoulement-suspects were not deported but their detention forced the British to sacrifice another aspect of international human rights legislation. More generally arguments for greater restrictive conditions for the recognition of refugees in Europe through the harmonisation of refugee policy at the EU level is accompanied by Member States arguing that this will save the principle of non-refoulement. ${ }^{44}$ The cumulative effect of these trends would in effect empty the 1951 Convention of any real content. Thus one of the most recent proposals that has been secretly discussed by ministers and civil servants in the European Council, was a new Directive (one of a raft in the harmonisation project started by the Treaty of Amsterdam) that would define European refugee/subsidiary protection. All new successful applicants for refugee or subsidiary protection status in the EU would have their situation regularly reviewed with the view of terminating their status as soon as possible. This would break a

\footnotetext{
${ }^{43}$ van Selm, forthcoming; Guild, forthcoming.

${ }^{44}$ Steiner, p. 147.
} 
principle of the Geneva Convention, which awards this status permanently. ${ }^{45}$ Furthermore, the European Council also wanted to strengthen the exclusion clauses of the Geneva Convention that deals with terrorists. Under Article 1F persons can be excluded from refugee status on grounds they have committed a crime against peace. They are also barred if they are a war criminal or have committed a crime against humanity. They are also excluded if they have committed a serious non-political crime outside of their country of refuge prior to admission; or they have been guilty of acts contrary to the principles and purposes of the United Nations. The European Council would like to add to their Directive articles that would exclude cruel crimes with an allegedly political objective from refugee status. This does not appear in the Geneva Convention, but since the Security Council ruled after September $11^{\text {th }}$ that terrorism is against the purposes and principles of the UN, it is covered by Article 1.F of the Geneva Convention. But the proposed EU Directive would also extend exclusion to persons who 'instigate or otherwise participate' in activities subject to the exclusion clause. This does not exist in the Geneva Convention and would be open to a much broader interpretation affecting those who were involved in liberation or opposition movements against an oppressive government and who were only suspected of alleged terrorist activity. Furthermore David Blunkett suggested at the March $28^{\text {th }} 2003$ meeting of the European Council that Albania and Croatia become venues for the screening of all refugees into Europe. In other words, the regionalisation of refugee and asylum policy that has proceeded apace in the 1990s and early 2000s would be capped off with this 'Australian' policy. This in effect would make it impossible for spontaneous asylum-seekers to seek asylum in a Member State and it would effectively make all such attempts illegal. An international quota system

\footnotetext{
${ }^{45}$ Guardian, 11 December 2002. Incidentally, this was proposal originally advanced by the Far Right
} 
would thus replace the right of asylum for the individual fleeing persecution. Temporary refugees caused by ethnic cleansing or war and the individual asylumseeker would thus, it seems, be treated officially under the same regime. But even now Blunkett's return to the 'Straw Plan' met with objections. Although many member states seemed to endorse it, they also wanted the blessing of Ruud Lubbers, UNHCR High Commissioner. He would only approve the plan if it was located within the EU and only entailed processing claimants from 'safe countries'. Otto Schily of Germany objected to the British plan because he felt it was too liberal, because it would reduce the distance asylum seekers would have to travel and thereby increase the total number of asylum seekers that the European Union would have to process! $!^{46}$

Earlier I argued that the Geneva Convention has been always under the mercy of economic and power politics considerations. Thus one could conclude that arguments about its sanctity are irrelevant. Nevertheless without this bedrock, the system of an international regime of asylum and refugee law would be replaced by the imperatives of technocratic 'securocrats' and the whims of charity. A world of less liberal certainties might reassure the public of Europe, weaken the arguments of the Far Right and lessen a problem that has sometimes threatened the future of incumbent politicians. However, this route would undermine one of the cardinal products of liberal democracy in Europe and would certainly go against the open society that European 'embedded liberalism ${ }^{177}$ has officially promoted.

\footnotetext{
Danish People's Party.

${ }^{46}$ D. Dombey, 'UK asylum proposals draw mixed response', Financial Times, 29/30 2003, p. 12.

${ }^{47}$ J. Hollifield, Immigrants, Markets and States: The Political Economy of Post-War Europe, Harvard University Press, Cambridge (MA), 1992.
} 